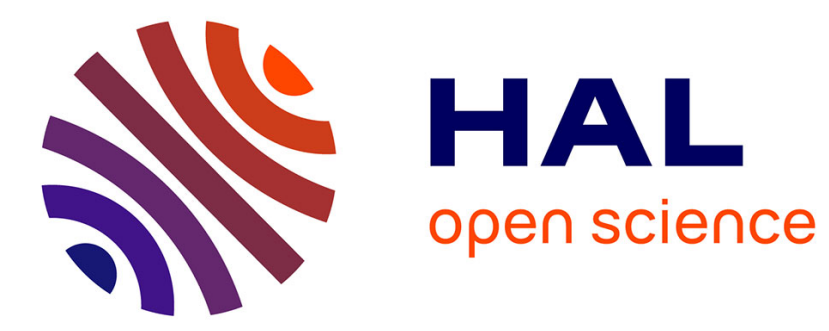

\title{
Supercritical CO2 extraction of oil from Jatropha curcas: An experimental and modelling study
}

Adil Mouahid, Halima Bouanga, Christelle Crampon, Elisabeth Badens

\section{To cite this version:}

Adil Mouahid, Halima Bouanga, Christelle Crampon, Elisabeth Badens. Supercritical CO2 extraction of oil from Jatropha curcas: An experimental and modelling study. Journal of Supercritical Fluids, 2018, 141, pp.2-11. 10.1016/j.supflu.2017.11.014 . hal-02114700

\section{HAL Id: hal-02114700 \\ https://hal-amu.archives-ouvertes.fr/hal-02114700}

Submitted on 29 Apr 2019

HAL is a multi-disciplinary open access archive for the deposit and dissemination of scientific research documents, whether they are published or not. The documents may come from teaching and research institutions in France or abroad, or from public or private research centers.
L'archive ouverte pluridisciplinaire HAL, est destinée au dépôt et à la diffusion de documents scientifiques de niveau recherche, publiés ou non, émanant des établissements d'enseignement et de recherche français ou étrangers, des laboratoires publics ou privés. 


\title{
Supercritical $\mathrm{CO}_{2}$ extraction of oil from Jatropha curcas: An experimental and modelling study
}

\author{
Adil Mouahid*, Halima Bouanga, Christelle Crampon, Elisabeth Badens
}

Aix Marseille Univ., CNRS, Centrale Marseille, M2P2, Marseille, France

G R A P H I C A L A B S T R A C T

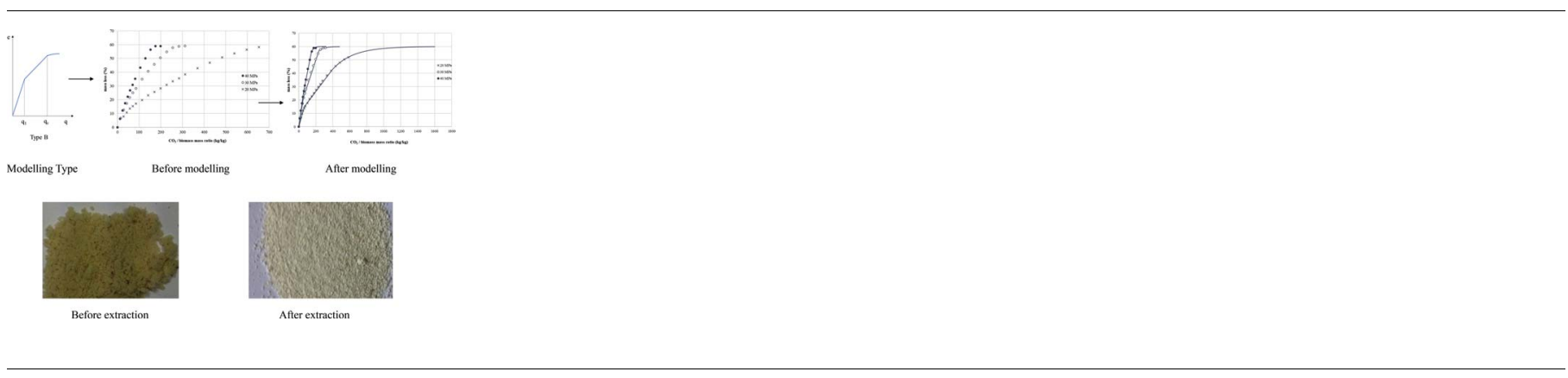

A R T I C L E I N F O

Keywords:

Supercritical $\mathrm{CO}_{2}$ extraction

Sovová's model

Jatropha curcas

\begin{abstract}
A B S T R A C T
Experimental and modelling investigations of supercritical $\mathrm{CO}_{2}$ extraction of oil from Jatropha curcas were conducted at a pressure range of 20-40 MPa and a temperature range of 313-333 $\mathrm{K}^{2}$ at a $\mathrm{CO}_{2}$ flow rate of $0.4 \mathrm{~kg} /$ h. The extraction yield was estimated to be about $0.6 \mathrm{~kg}$ oil $/ \mathrm{kg}_{\text {biomass }}$ for all experiments. The model of broken and intact cells published by Sovová was applied. It was found that the extraction of type B was the most suited extraction type to apply as the experimental extraction curves exhibit three parts. Whatever the pressure and the temperature applied, the asymptotic yield at infinite time was found to be the same. At $20 \mathrm{MPa}$, increasing the temperature from 313 to $323 \mathrm{~K}$ enhances the extraction kinetics. A retrograde solubility zone was found at 30 and $40 \mathrm{MPa}$. The Jatropha curcas oil solubility in $\mathrm{SC}-\mathrm{CO}_{2}$ was determined and the data were modelled with the Chrastil equation.
\end{abstract}

\section{Introduction}

On a worldwide scale, the demand for energy continues to increase while fossil fuels are increasingly being discredited. One of the current ways intended to supplant fossil fuels is the production of biofuels. Jatropha curcas (JC) is a promising plant for such application as its oil can contain more than $75 \%$ of total lipids and is present in the range of $40-60 \mathrm{~g}$ oil/100 $\mathrm{g}$ [1-7]. The advantage of JC compared to rapeseed or sunflower seeds, is that this plant adapts well to dry and hot climates and as such, does not require much water. Above all, the cultivation of this plant does not compete with food crops. As a consequence, JC seeds represent an encouraging source of oil from which biodiesel may be derived by transesterification [3-6,8-16]. JC oil can be extracted by different methods, however mechanical extraction methods [15,17-19] are generally preferred because the operational costs are low and they can easily be carried out by semi-skilled operators. Furthermore, the residue can be used for biogas production. On the down side, however, the extraction yield is lower than solvent extraction methods. Indeed, the rate of oil recovery obtained by mechanical press methods is comprised between 69 and $86 \%$ while the yield obtained by classical organic solvent, such as $n$-hexane, extraction methods are comprised between 70 and $99 \%$ depending on extraction time and solvent type

\footnotetext{
* Corresponding author.

E-mail address: adil.mouahid@univ-amu.fr (A. Mouahid).
} 


\begin{tabular}{|c|c|c|c|}
\hline \multicolumn{2}{|c|}{ Nomenclature } & $R e$ & Reynolds number \\
\hline & & $R e_{p}$ & Reynolds number for fluid flow through a porous media \\
\hline$a_{g}$ & Specific surface area of the microalgae powder $\left(\mathrm{m}^{-1}\right)$ & $\mathrm{T}$ & Temperature (K) \\
\hline$a_{s}$ & $\begin{array}{l}\text { Specific area between the regions of intact and broken } \\
\text { cells }\left(\mathrm{m}^{-1}\right)\end{array}$ & $\begin{array}{l}t \\
t_{f}\end{array}$ & $\begin{array}{l}\text { Extraction time (s) } \\
\text { Extraction time to achieve the } \mathrm{SC}-\mathrm{CO}_{2} \text { extraction (h) }\end{array}$ \\
\hline$C_{u}$ & Solute content in the untreated solid ( $\mathrm{kg}$ oil $\left./ \mathrm{kg}_{\text {biomass }}\right)$ & V & Solvent velocity $(\mathrm{m} / \mathrm{s})$ \\
\hline$D_{21}$ & Diffusion coefficient of oil(2) to $\mathrm{CO}_{2}(1)\left(\mathrm{m}^{2} / \mathrm{s}\right)$ & $x_{t}$ & Transition concentration ( $\mathrm{kg}$ oil $/ \mathrm{kg}_{\text {insolublesolid }}$ ) \\
\hline$d_{p}$ & JC mean particle diameter $(\mathrm{m})$ & $x_{u}$ & Concentration in the untreated solid \\
\hline$e^{r}$ & Extraction yield ( $\mathrm{kg}$ oil $/ \mathrm{kg}_{\text {insolublebiomass }}$ ) & & $\left.\mathrm{kg}_{\text {insolublebiomass }}\right)$ \\
\hline$e^{\prime}$ & Mass loss ( $\mathrm{kg}$ oil $/ \mathrm{kg}_{\text {biomass }}$ ) & $y_{s}$ & Solute solubility $\left(\mathrm{kg}_{\mathrm{oil}} / \mathrm{kg} \mathrm{CO2}\right)$ \\
\hline E & Amount extract $(\mathrm{kg})$ & & \\
\hline$k_{f}$ & Fluid-phase mass transfer coefficient $\left(\mathrm{s}^{-1}\right)$ & \multirow{2}{*}{\multicolumn{2}{|c|}{ Greek letters }} \\
\hline$k_{s}$ & Solid-phase mass transfer coefficient $(\mathrm{m} / \mathrm{s})$ & & \\
\hline$n$ & Number of experimental point & $\gamma$ & Solvent to matrix ratio in the bed $\left(\mathrm{kg}_{\text {solvent }} / \mathrm{kg}_{\text {insolublesolid }}\right)$ \\
\hline$N$ & Solid charge in the extractor $(\mathrm{kg})$ & $\varepsilon$ & Bed void fraction \\
\hline$N_{m}$ & Charge of insoluble solid (kg) & $\rho_{b}$ & Solid bulk density $\left(\mathrm{kg} / \mathrm{m}^{3}\right)$ \\
\hline$q$ & $\begin{array}{l}\left.\text { Relative amount of the passed solvent ( } \begin{array}{lll}\mathrm{kg} & \mathrm{CO} / \\
\mathrm{kg}_{\text {insolublebiomass }}\end{array}\right)\end{array}$ & $\begin{array}{l}\rho_{\mathrm{CO} 2} \\
\rho_{s}\end{array}$ & $\begin{array}{l}S C-\mathrm{CO}_{2} \text { density }\left(\mathrm{kg} / \mathrm{m}^{3}\right) \\
\text { Biomass density }\left(\mathrm{kg} \text { insolublesolid } / \mathrm{m}_{\text {solidphase }}{ }^{3}\right)\end{array}$ \\
\hline $\begin{array}{l}q \\
\dot{Q}\end{array}$ & $\begin{array}{l}\text { Specific flow rate }\left(\mathrm{kg}_{\text {solvent }} / \mathrm{kg}_{\text {solid }} / \mathrm{s}\right) \\
\text { Solvent flow rate }(\mathrm{kg} / \mathrm{s})\end{array}$ & $\mu$ & SC- $\mathrm{CO}_{2}$ dynamic viscosity (Pa.s) \\
\hline$r$ & Grinding efficiency or fraction of broken cells & & \\
\hline
\end{tabular}

[20-22]. However, classical organic solvents are known to be pollutant and non-selective, which has led to the investigation of other extraction methods for JC oil [16,23-26]. The supercritical $\mathrm{CO}_{2}\left(\mathrm{SC}-\mathrm{CO}_{2}\right)$ extraction method allows a green and rather selective extraction, depending on the operating pressure and temperature, of non-polar compounds, particularly triglycerides that lead to biodiesel after transesterification. These advantages encourage researchers to evaluate the feasibility of SC- $\mathrm{CO}_{2}$ oil extraction from JC and its use for biodiesel production [27-37]. For the sake of simplicity, the operating conditions of the studies dealing with the SC- $\mathrm{CO}_{2}$ extraction of oil from JC with pure $\mathrm{CO}_{2}$ are reported in Table 1.

In 2009, Chen et al. [33] studied the effects of pressure, temperature and solvent to solid ratio on the extraction efficiency of triglycerides from JC seeds by using SC- $\mathrm{CO}_{2}$ extraction. The authors used a response surface methodology to determine the effects of the operating conditions on the concentration of triglycerides present in the extracted oil. They showed that pressure is most effective in enhancing the recovery of triglycerides, however the main factor that affects the concentration of triglycerides is temperature and solvent to solid ratio value. They also demonstrated that $\mathrm{SC}-\mathrm{CO}_{2}$ extracts exhibit a higher concentration of triglycerides than Soxhlet extracts obtained at $342 \mathrm{~K}$ with $n$-hexane. Chen et al. [28] investigated the SC- $\mathrm{CO}_{2}$ extraction of triglycerides from powdered JC kernels followed by subcritical hydrolysis and supercritical methylation of the extracted oil. They demonstrated that supercritical methylation preceded by subcritical hydrolysis of the extracted oil is a feasible two-step process for producing biodiesel. Chen et al. [29] investigated the use of the $\mathrm{SC}-\mathrm{CO}_{2}$ for the extraction of triglycerides from de-shelled JC seeds. They used a response surface methodology to evaluate the effects of pressure, temperature and solvent to solid ratio on total yield, concentration of triglycerides and recovery of triglycerides. They showed that pressure and solvent to solid ratio significantly affect the quality of the extracted oil. Ghoreishi et al. [27] used SC- $\mathrm{CO}_{2}$ to extract oil from JC seeds in order to study two different catalytic reactions (transesterification with an alkali catalyst and esterification with an acidic catalyst) for biodiesel production. They showed that the alkali catalyst transesterification reaction is more effective than the acidic esterification. Tsuchiya et al. [36] evaluated the performance of an unpurified extracted SC- $\mathrm{O}_{2}$ oil as a fuel. The authors used a large extraction device to produce adequate amounts of oil for the combustion tests. In order to use the extracted oil as a substitute of biodiesel they performed the extraction at operating conditions which allowed the selective extraction of triglycerides from JC seeds [37]. According to this study, when the extracted oil was used to fuel a diesel engine, no remarkable differences in thermal efficiency and specific fuel consumption was noticed compared with diesel fuel. Nevertheless, it is necessary to perform a long-term evaluation as the combustion tests were conducted for very short duration. Min et al. [34] investigated the extraction kinetics of JC oil and its solubility in $\mathrm{SC}-\mathrm{CO}_{2}$. The solubility

Table 1

Experimental operating conditions of the SC- $\mathrm{CO}_{2}$ extraction studies performed on JC kernels. (-) no data reported.

\begin{tabular}{|c|c|c|c|c|c|c|c|c|c|c|c|}
\hline Refs. & Year & $T(\mathrm{~K})$ & $P(\mathrm{MPa})$ & $\mathrm{CO}_{2}$ flowrate & $t(\min )$ & $d_{p}(\mu \mathrm{m})$ & $\begin{array}{l}\text { Growing } \\
\text { environment }\end{array}$ & $N^{t k k} \times 10^{3}(\mathrm{~kg})$ & $\begin{array}{l}\text { Study of } \mathrm{SC}-\mathrm{CO}_{2} \\
\text { extraction } \\
\text { kinetics }\end{array}$ & $\begin{array}{l}\text { Determination of oil } \\
\text { solubility in } \mathrm{SC}-\mathrm{CO}_{2}\end{array}$ & $\begin{array}{l}\text { Extraction } \\
\text { curve } \\
\text { modelling }\end{array}$ \\
\hline [33] & 2009 & $313-333$ & $25-35$ & $25 \mathrm{~L} / \mathrm{min}$ & 300 & - & Indonesia & 30 & No & No & No \\
\hline [28] & 2010 & 333 & 35 & - & 300 & $>840$ & Taiwan & 30 & No & No & No \\
\hline [34] & 2010 & $308-358$ & $20-50$ & $1.5-2 \mathrm{~L} / \mathrm{min}$ & 350 & $250-400$ & China & 13 & Yes & Yes & No \\
\hline [32] & 2011 & 313 & 30.4 & $1 \mathrm{dm}^{3} / \mathrm{min}$ & $5-99$ & $300-600$ & South-Africa & 1 & No & Yes & No \\
\hline [29] & 2012 & $313-333$ & $25-35$ & $25 \mathrm{~mL} / \mathrm{min}$ & $120-300$ & $>841$ & Taiwan & 15 & No & No & No \\
\hline [27] & 2013 & $313-333$ & $20-30$ & $1-2 \mathrm{~mL} / \mathrm{min}$ & $40-60$ & - & - & - & No & No & No \\
\hline [37] & 2013 & $318-323$ & 30 & $15 \mathrm{~mL} / \mathrm{min}$ & $240-720$ & - & Philippines & 60 & No & Yes & No \\
\hline [31] & 2015 & 323 & 30 & $3.23 \times 10^{-3} \mathrm{~kg} / \mathrm{min}$ & 1800 & 900 & Malaysia & 50 & No & No & $\begin{array}{l}\text { Reverchon } \\
\text { - Sesti Osseo }\end{array}$ \\
\hline [35] & 2015 & $313-333$ & $20-50$ & $9.86-10.4 \mathrm{~g} / \mathrm{min}$ & $135-250$ & $250-450$ & Spain & $27.9-35.8$ & Yes & Yes & No \\
\hline [36] & 2016 & 313 & 30 & $600 \mathrm{~kg} / \mathrm{h}$ & $22-129$ & $2000-3300$ & Philippines & 42900 & No & No & No \\
\hline
\end{tabular}

* Single unit conversion was not performed because of the lack of information in the reported studies.

** N:solid charge in the extractor. 
data were modelled by modified Chrastil equation, but the extraction curves presented were not modelled. Breet et al. [32] converted the JC oil extracted by $\mathrm{SC}-\mathrm{CO}_{2}$ to biodiesel. In their study, the analysis of the extracted oil before and after transesterification to fatty acid methyl esters proved that the composition of the product meets the required commercial biodiesel standard. The authors also estimated the solubility of JC oil in $\mathrm{SC}^{-\mathrm{CO}_{2}}$. Micic et al. [31] studied the modelling of SC$\mathrm{CO}_{2}$ extraction curves of $\mathrm{JC}$ at $323 \mathrm{~K}$ and $30 \mathrm{MPa}$. The curve was modelled using the modified Reverchon-Sesti Osteo model equation. The solubility of JC oil in SC- $\mathrm{CO}_{2}$ was not determined. Fernandez et al. [35] investigated the $\mathrm{SC}-\mathrm{CO}_{2}$ extraction and fractionation of JC oil for biodiesel production. They showed that the extraction yield of JC oil strongly depends on the pressure and particle diameter of the seed. They obtained the best yield $\left(0.312 \mathrm{~kg}\right.$ oil $\left./ \mathrm{kg}_{\text {seed }}\right)$ at $50 \mathrm{MPa}, 313 \mathrm{~K}$ and for a particle diameter of $0.27 \mathrm{~mm}$. They showed that the fatty acid content decreases when the extraction pressure increases. The solubility of the JC oil in SC- $\mathrm{CO}_{2}$ was estimated by considering the slope of the first and linear part of the extraction curves.

From these studies, it appears that the quality of the oil extracted by $\mathrm{SC}-\mathrm{CO}_{2}$ extraction from JC is suitable to biodiesel application. However, it is necessary to emphasize that the study of the SC- $\mathrm{CO}_{2}$ extraction kinetics has only been investigated in two articles [34,35] and only one study has dealt with the modelling of the extraction curve at $30 \mathrm{MPa}, 323 \mathrm{~K}$ and a $\mathrm{CO}_{2}$ flowrate of $3.23 \times 10^{-3} \mathrm{~kg} / \mathrm{min}$ [31]. Few studies deal with the solubility of JC oil in $\mathrm{SC}^{-} \mathrm{CO}_{2}$ by taking into account the slope of the first part of the extraction curve $[34,35]$ or by direct experimental measurements [32,37,38]. Furthermore, the growing environment of JC is different in each study (Table 1) which can lead to different oil compositions and hence differences in solubility values. The aim of this work is to study the extraction kinetics of the extracted oil from JC by using the model of broken and intact cells (BIC) developed by Sovová [39]. The BIC model was chosen because it is accurate, well adapted to natural products and versatile: it has been applied as much as for plant materials as for microalgae [39-43]. The solubility of JC oil in SC- $\mathrm{CO}_{2}$ was also calculated and oil analysis for each experiment was performed.

\section{Materials and methods}

\subsection{Raw materials and chemicals}

JC seeds were obtained from the Indian company Vanashree Agrotech. The seeds were de-shelled and the kernel were grinded and sieved at a particle size distribution of $300-500 \mu \mathrm{m}$. The water content of the grinded kernels was estimated at about $4 \mathrm{wt} \%$, hence water should not affects the extraction as the value is lower than $20 \mathrm{wt} \%$ [41]. Before $\mathrm{SC}-\mathrm{CO}_{2}$ extraction, the grinded biomass was stored at $274 \mathrm{~K}$ to avoid the chemical degradation of the lipids. $\mathrm{CO}_{2}$ was provided by Air Liquide (France) with a purity of $99.7 \%$, $n$-hexane $(99.8 \%$, Carlo Erba, France) was used to make the organic solvent extraction to determine the total oil content of the kernels.

\subsection{Experimental setup}

The extraction unit used for this study is a laboratory scale extraction device supplied by Separex (Champigneulles, France). The extraction autoclave is a stainless-steel vessel of $10 \mathrm{~cm}^{3}$ placed in a heater. This autoclave has at its ends two flat stainless-steel frit filters (pore diameter distribution of 5-15 $\mu \mathrm{m}$ ). The operating and the details of the extraction device has already been described in other studies $[41,43]$. For each experiment, the mass introduced in the extraction autoclave was comprised between 7 and $8 \mathrm{~g}$. Regarding the small charges used for $\mathrm{SC}-\mathrm{CO}_{2}$ extraction experiments, the efficiency of the extraction was estimated relative to the mass losses of the sample in the extraction autoclave (Eq. (1)) $\mathrm{e}^{\prime}(\%)=\frac{\text { mass extracted }(\mathrm{kg})}{\text { mass introduced in the extractor }(\mathrm{kg})} \times 100$

SC- $\mathrm{CO}_{2}$ extraction experiments were conducted at pressures of 20, 30 and $40 \mathrm{MPa}$, temperatures of 313,323 and $333 \mathrm{~K}$, and a $\mathrm{CO}_{2}$ flowrate of $0.4 \mathrm{~kg} / \mathrm{h}$. The extraction curves were plotted as the variation of the mass losses of the sample as a function of the $\mathrm{CO}_{2}$ /biomass mass ratio. At the end of an extraction experiment, the extracted oil was collected in $5 \mathrm{~mL}$ of $n$-hexane.

\subsection{Scanning electron microscopy (SEM)}

JC grinded kernels were observed with a Scanning Electron Microscope before extraction experiments. The visualizations were made on a Hitachi TM3000 Tabletop Microscope at $15 \mathrm{kV}$. The sample powders of JC were deposited on an adhesive pastille and metallized with a thin layer of Au-Pd to allow a better conduction of the sample and a better visualization. The metallization time did not exceed 30s.

\subsection{Assumptions}

The supercritical fluid extraction models presented in the literature have been built by making different assumptions on the flow pattern and the interactions between the extracted solute and the solid matrix. Those characteristics depend on the experimental conditions and on the extraction autoclave dimensions. In order to target the appropriate equations to our system, we have determined the flow pattern and the type of interactions which may occur during the $\mathrm{SC}-\mathrm{CO}_{2}$ extraction process. The internal diameter (D) of the autoclave is $12.5 \mathrm{~mm}$ and the length (L) is $160 \mathrm{~mm}$. The Reynolds number $(R e)$ describing the flow of $\mathrm{SC}-\mathrm{CO}_{2}$ in the empty autoclave is 184 . This value of $R e$ corresponds to a laminar flow in a cylindrical tube. For fluid flow through a porous media, the Reynolds number $R e_{p}$ is given by Eq. (2)

$\operatorname{Re}_{p}=\frac{\rho_{\mathrm{CO}_{2}} V}{\mu a_{g}(1-\varepsilon)}$

Where $\rho_{\mathrm{CO} 2}$ is SC- $\mathrm{CO}_{2}$ density, $V$ is the SC- $\mathrm{CO}_{2}$ velocity, $\mu$ is the solvent dynamic viscosity, $a_{g}$ is the specific surface area of JC powder and $\varepsilon$ is the bed void fraction. As the extraction bed was supposed to be composed of spherical particles, $a_{g}$ is then equal to $6 / d_{p}$ where $d_{p}$ is the mean JC particle diameter. The bed void fraction $\varepsilon$ of JC was estimated by immersing a known amount of biomass powder residue (powder of JC after extraction) in a test tube containing a known volume of absolute ethanol. The volume displaced allows us to calculate the density of JC $\rho_{s}$. The JC density $\rho_{s}$ was estimated at $642.5 \mathrm{~kg} / \mathrm{m}^{3}$. Knowing the bulk density $\rho_{b}$ it is possible to determine $\varepsilon$ by using Eq. (3).

$\varepsilon=1-\frac{\rho_{b}}{\rho_{s}}$

The value of the bed void fraction $\varepsilon$ of JC was estimated at 0.7 after a repeatability test consisting of three experiments. This value was the same whatever the operating conditions of the extraction experiments. The calculated values of $R e_{p}$ varied from 1.8 to 3.3. In all cases, the values of $R e_{p}$ are lower than 10 and close to 1 , which correspond to the laminar or transitory flow regime. Considering that $\mathrm{L}>>\mathrm{D}$ and the values of $R e$ and $R e_{p}$, we can assume that the flow pattern of SC-CO $\mathrm{CO}_{2}$ in the extraction autoclave is plug flow. Therefore, axial dispersion was supposed to be negligible.

\section{Modelling}

\section{1. $\mathrm{SC}-\mathrm{CO}_{2}$ extraction curves}

The extraction curves were modelled using Sovová's mathematical model for supercritical fluid extraction of natural products [39]. This model takes into account the structure of the biological material studied 
and accounts for the sudden reduction in extraction rate after the first extraction period that is observed during $\mathrm{SC}-\mathrm{CO}_{2}$ extractions from seeds.

According to the study published by Sovová, the extraction can be of type A, B, C or D. In the decision on extraction type it is possible to refer to the aspect of the extraction curves (Fig. 1): if the first part of the extraction curve consists of one straight section, the type is A or D. If it consists of two straight sections, it is of type B or C. The shape of the extraction curves obtained in this study exhibits three parts, this observation was also pointed out by Min et al. [34]. Hence, the extraction type is B or C. For type C, the second straight line starts very early, at a relative amount of the passed solvent $q$ not far from 1 . In this study the second straight line starts at $q>>1$ for all extraction curves. Hence, extraction of type $B$ is the most suitable extraction type to describe the extraction curves in this work.

In extraction of type $\mathrm{B}$, the first part of the extraction curve is composed of two straight lines (Fig. 1) given by Eqs. (4)-(6). The first straight line (Eq. (4)) is controlled by solute solubility in $\mathrm{SC}-\mathrm{CO}_{2}$. The second straight line (Eq. (6)) indicates that the solute concentration in the biomass is considerably reduced and the equilibrium is controlled by solute-matrix interactions. This implies that the fluid-phase equilibrium is much lower than the solute solubility. The transition between the two straight lines occurs at the transition concentration $x_{t}$. The phase equilibrium no longer depends on solubility but on the partition coefficient $K$ which represents the constant of proportionality of the linear relationship between solid and fluid-phase concentrations. The transition concentration $x_{t}$ is equal to the matrix capacity for interaction with the solute, if $x_{t}=0$ there is no solute-matrix interaction. Solute-matrix interactions can be related to the desorption of the solute from the biomass. The last part of the extraction curve, described by Eq. (7), is controlled by solute diffusion from intact cells to broken cells. The extraction curve of type B are described by considering Eqs. (4), (6),(7):

\section{- First part of the extraction curve}

$e=q y_{s}$ for $0 \leq q \leq q_{1}$

with e, the extraction yield $\left(\mathrm{kg}_{\text {oil }} / \mathrm{kg}_{\text {insolublebiomass }}\right)$

$q_{1}=\frac{r\left(x_{u}-x_{t}\right)-\gamma K x_{t}}{y_{s}-K x_{t}}$

$e=q_{1} y_{s}+\left(q-q_{1}\right) K x_{t}$ for $q_{1} \leq q \leq q_{c}$

- Second part of the extraction curve

$e=x_{u}\left[1-C_{1} \exp \left(-C_{2} q\right)\right]$ for $q>q_{c}$

A straight line of slope $y_{s}$, which represents the solubility of the
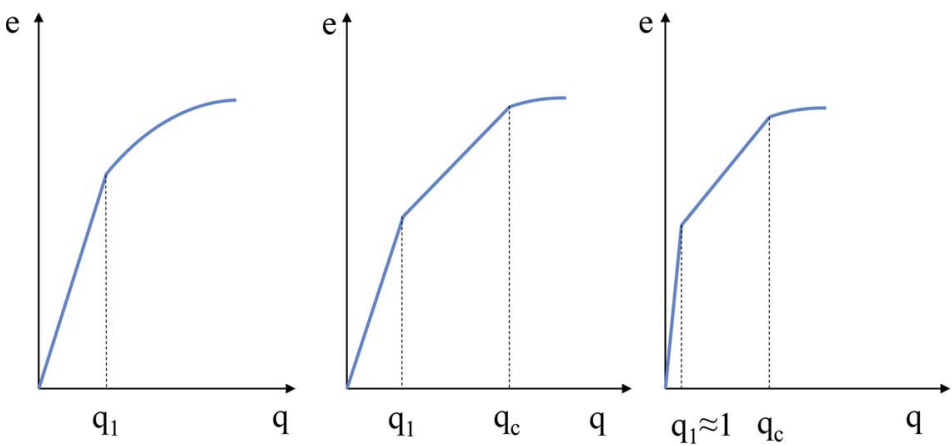

Type A
Type B

extracted oil in SC- $\mathrm{CO}_{2}$ is fitted to the first part of the extraction curve (Eq. (4)).The values of $q_{c}$ and $q_{1}$ were determined by taking into account the fact that:

- $\mathrm{q}_{\mathrm{c}}$ is the value of $q$ at the crossing point with the estimate for the second part of the extraction curve according to Eq. (6) and

- $\mathrm{q}_{1}$ is the value of $q$ at the crossing point with the first linear part (Eq. (4)) and the second straight part (Eq. (6)) considering the expression of $q_{1}$ in Eq. (5).

The second part of the extraction curve ( $q>q_{c}$ ) is described by Eq. (7) by adjusting constant parameters $C_{1}$ and $C_{2}$. Estimations of parameters $k_{s} a_{s}$, the mass transfer coefficient, and $r$, the fraction of the broken cells, can be obtained by considering Eq. (8) to 13:

$r=1-C_{1} \exp \left(-C_{2} q_{c}\right)$

$k_{s} a_{s}=\frac{(1-r)(1-\varepsilon) \dot{Q} C_{2}}{N_{m}\left[1-\left((1-r) C_{2} / K\right]\right.}$ for $x_{t}>0$

With:

$e=\frac{E}{N_{m}}$

$q=\frac{\dot{Q} t}{N_{m}}$

$N_{m}=\left(1-C_{u} N\right)$

$C_{u}=\frac{x_{u}}{1+x_{u}}$

Where $E$ is the amount of extract $(\mathrm{kg})$ and $\dot{Q}$ is the solvent flowrate $(\mathrm{kg} /$ s) and $\mathrm{C}_{\mathrm{u}}$ is the solute content in the untreated solid. The solute concentration in the untreated solid $x_{u}$ (with insoluble solid as reference) was supposed equal to the asymptotic extraction yield at infinite time. The adjustable parameters $C_{1}$ and $C_{2}$ were calculated by minimizing the sum of least squares between the experimental and calculated values of $e$. The absolute average relative deviation (AARD) given in Eq. (14), was used to evaluate the efficiency of the model.

$A A R D(\%)=\frac{100}{n} \sum\left|\frac{\text { Experimental yield }- \text { Calculated yield }}{\text { Experimental yield }}\right|$

For more details on the assumptions made in this section and the determination of the model parameters, one can refer to previous works [39-41]. The modelled extraction curves were expressed as the variation of $e^{\prime}$ as a function of the mass ratio $\mathrm{CO}_{2}$ /biomass. As additional information, which can be useful for further studies, it was decided to give the binary diffusion coefficient $D_{21}$ and the fluid phase mass transfer coefficient $k_{f}$ of the extracted JC oil in SC- $\mathrm{CO}_{2}$. These properties were calculated by the correlations given in the works of $\mathrm{He}$ [44] and Tan et al. [45]. The average molar mass of JC oil was calculated at

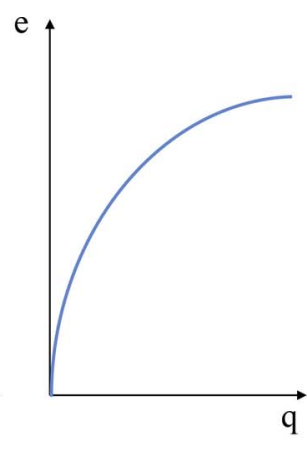

Type D
Fig. 1. Shapes of the extraction curves for the different types of extraction reported in the Sovovás mathematical model. 
$877 \mathrm{~g} / \mathrm{mol}$ according to the values properties reported by Yang et al. [6].

\subsection{JC oil solubility in $\mathrm{SC}-\mathrm{CO}_{2}$}

The solubility of JC oil in SC- $\mathrm{CO}_{2}$ was calculated by considering the slope of the first part of the extraction curve (Eq. (4)). The experimental data were modelled by the Chrastil model given in Eq. (15). This model considers that one molecule of solute can associate with $k$ molecules of solvent forming a solvated complex molecule in equilibrium with the fluid.

$\ln \left(y_{s}\right)=k \ln \rho_{\mathrm{CO}_{2}}+\frac{a}{T}+b$

With:

- $k$ : the association number

- $a$ : which depends on the heat of solvation and vaporization of solute

- b: a parameter which is dependent on the molecular weight of species

The parameters $k, a$ and $b$ were adjusted on the experimental data of $y_{s}$

\section{Results and discussions}

\section{1. n-hexane extraction}

The total oil content of the JC kernel was determined by $n$-hexane extraction carried out on $6 \mathrm{~g}$ of grinded and sieved $(300-500 \mu \mathrm{m}) \mathrm{JC}$ kernels in $100 \mathrm{~mL}$ of $n$-hexane. The extraction was performed at $323 \mathrm{~K}$ over 3 days. The total mass loss of the oil extracted from JC kernels was determined at about $61.7 \mathrm{wt} \%$. This result is in good agreement with a previous study [30].

\section{2. $\mathrm{SC}-\mathrm{CO}_{2}$ extraction experiments}

\subsubsection{General finding}

The extraction curves are presented in Fig. 2. It can be seen that for all experiments, when it was possible to perform extraction until its end, the maximal mass loss reached is about $60 \%$. This value is very close to the value obtained by $n$-hexane extraction $(61.7 \mathrm{wt} \%)$. The aspect of JC powdered kernels before and after $\mathrm{SCCO}_{2}$ extraction is given in Fig. 3. Before extraction (Fig. 3(a)) the biomass aspect is very colored (yellow) and oily, after extraction (Fig. 3(b)) the residue aspect is dry and totally discolored. It was noticed that after $\mathrm{SC}-\mathrm{CO}_{2}$ extraction the biomass residue still have the same aspect. This aspect suggests that all neutral lipids were extracted. Consequently, it can be considered that it was possible to extract all the oil contained in JC kernels by SC$\mathrm{CO}_{2}$ whatever the operating conditions. This result is of prime importance for modelling studies as it gives the possibility to make predictions if the experimental extraction curve could not be performed until the end. Furthermore, this tendency is in agreement with previous studies $[34,35]$. Indeed, it can be seen in these studies that the asymptotic yield at infinite time seems to reach a same maximal value (about $52 \mathrm{wt} \%$ ), close to the value obtained by Soxhlet extraction method (about $56 \mathrm{wt} \%$ ), whatever the conditions of pressure and temperature at a constant $\mathrm{CO}_{2}$ flowrate. Hence, the value of $C_{u}$ was fixed at $0.6 \mathrm{~kg}_{\text {oil }} / \mathrm{kg}_{\text {biomass }}$ for all modelling calculations.

The surface structure of JC observed by SEM at scales of 300 and $500 \mu \mathrm{m}$ is shown in Fig. 3(c) and (d). It can be seen that the surface structure is highly craked by the grinding process indicating that the latter was very effective.

\subsubsection{Effects of pressure and temperature}

The modelled extraction curves showing the effects of pressure and temperature are respectively given in Figs. 2 and 4. In Fig. 2, at a fixed temperature, increasing pressure from 20 to $40 \mathrm{MPa}$ enhances the extraction kinetics. This tendency is in good agreement with the studies of Min et al. [34] and Fernandez et al. [35]. In Fig. 4, at a pressure of $20 \mathrm{MPa}$ an increase of temperature from 323 to $333 \mathrm{~K}$ leads to a decrease in the extraction kinetics. The same tendency was observed at 30 and $40 \mathrm{MPa}$ when increasing the temperature from 313 to $333 \mathrm{~K}$. At $40 \mathrm{MPa}$, the extraction curves were found to be close at 323 and $333 \mathrm{~K}$. The deviation between the two extraction curves was about $5 \%$. The effects of temperature observed in this study can be explained by the presence of a retrograde solubility zone at a pressure of 20 and up to $40 \mathrm{MPa}$. In $\mathrm{SC}-\mathrm{CO}_{2}$ extraction, when the temperature increases the solute vapor pressure increases while the $\mathrm{SC}-\mathrm{CO}_{2}$ density decreases. Increasing the solute vapor pressure enhances the extraction but the decrease of the $\mathrm{SC}-\mathrm{CO}_{2}$ density disadvantages the extraction. In this study, when increasing the temperature at 20 up to $40 \mathrm{MPa}$, the decrease of $\mathrm{SC}-\mathrm{CO}_{2}$ density overtakes the increase of solute volatility.

The extraction curves published by Min et al. [34] were plotted reporting the variation of oil yield $(\mathrm{Y})$ pressures versus the volume of $\mathrm{CO}_{2}\left(\mathrm{VCO}_{2}\right)$ at different pressures for a fixed temperature. In order to make comparisons with our results, it was decided to plot their results by showing variation of temperature at single pressure in Fig. 5. The authors reported that increasing the temperature from 308 to $328 \mathrm{~K}$ at $20 \mathrm{MPa}$ (Fig. 5(a)) decreased the oil yield $Y$ (amount of oil extracted as a mass percentage of the original kernels). From Fig. 5, the following remarks can be made: at $30 \mathrm{MPa}$ (Fig. 5(b)) the extraction curves overlap whatever the temperature. At 40 and $50 \mathrm{MPa}$ Fig. 5(c) and (d), the extraction curves are very close to each other (the deviation was about 5\%) even if the extraction kinetics are slightly improved by increasing the temperature from 308 to $328 \mathrm{~K}$. Fernandez et al. [35] reported the effects of temperature at $50 \mathrm{MPa}$, pointing out that increasing the temperature from 313 to $333 \mathrm{~K}$ increased the extraction kinetics but from 323 to $333 \mathrm{~K}$, this increase was less pronounced as the two extraction curves reported at these temperatures are very close to each other and reach the same asymptotic yield.

The differences between our study and the results reported by Min et al. [34] can be explained by the different growing environments and harvest time of JC. Considering the results reported by Min et al. [34] and Fernandez et al. [35], it is possible to suppose that the retrograde solubility zone ends at a pressure threshold below $40 \mathrm{MPa}$ while in this study, the retrograde solubility zone goes up to $40 \mathrm{MPa}$. It was not possible to determine the threshold in this study since the maximum working pressure of the extraction apparatus is $45 \mathrm{MPa}$. The best
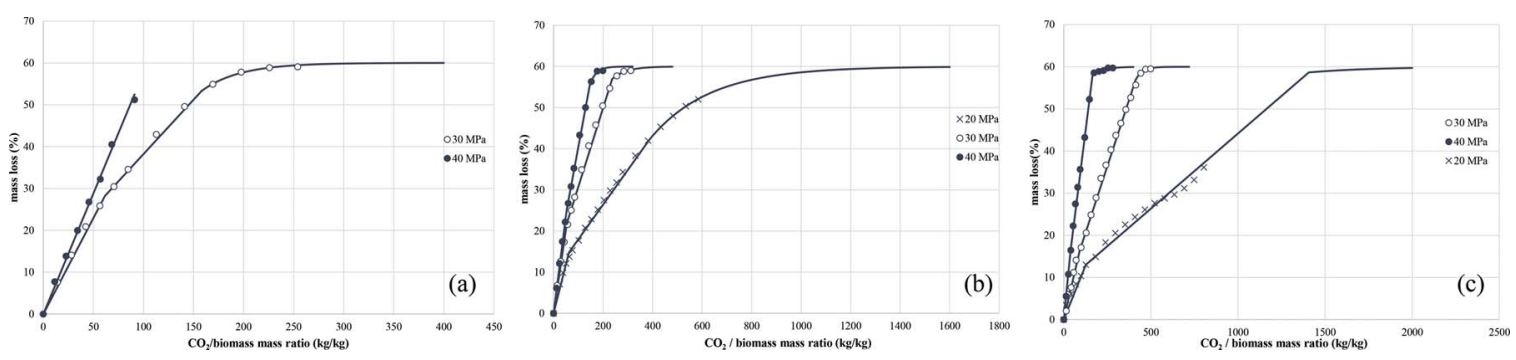

Fig. 2. Experimental and modelled JC SC- $\mathrm{CO}_{2}$ extraction curves: effects of pressure (a) $313 \mathrm{~K}$, (b) $323 \mathrm{~K}$, (c) $333 \mathrm{~K}$. 

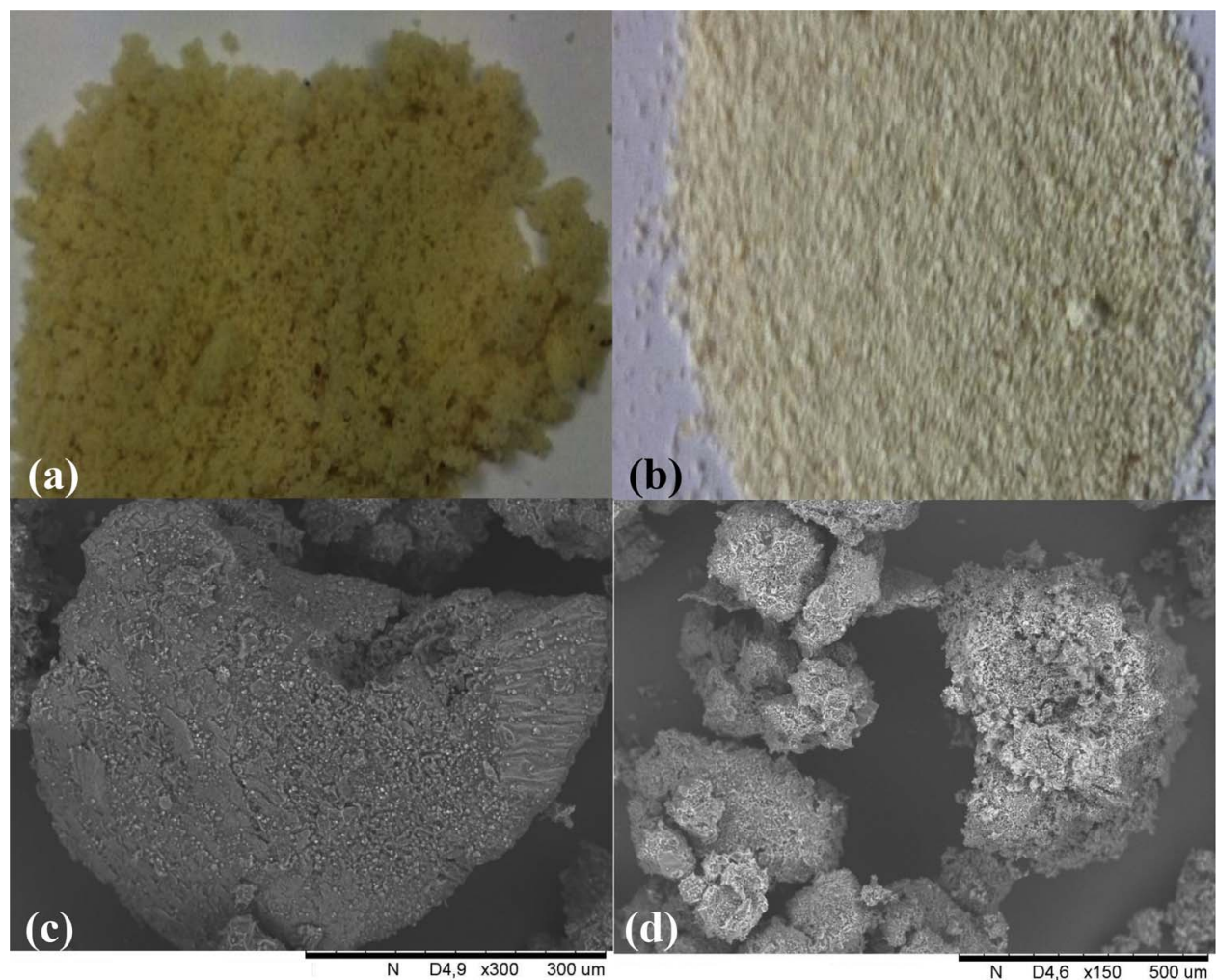

Fig. 3. grinded and sieved JC kernels (a) before extraction, (b) after extraction, (c) \& (D) SEM before extraction.

(b)
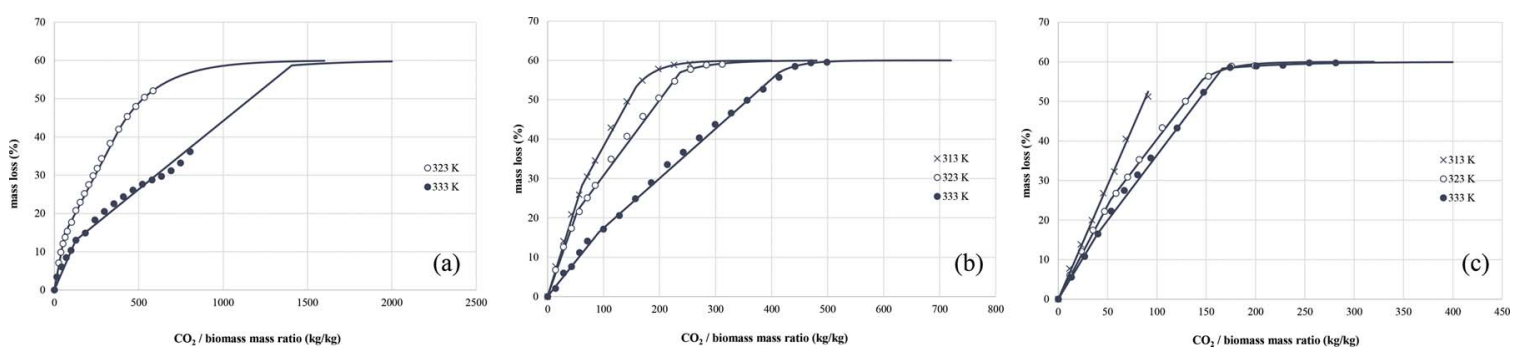

Fig. 4. Experimental and modelled JC SC- $\mathrm{CO}_{2}$ extraction curves: effects of temperature (a) $20 \mathrm{MPa}$, (b) $30 \mathrm{MPa}$, (c) $40 \mathrm{MPa}$.

extraction kinetics were obtained at $40 \mathrm{MPa}$ and $313 \mathrm{~K}$.

\subsubsection{JC oil solubility in $\mathrm{SC}-\mathrm{CO}_{2}$}

The solubility of JC oil was determined by calculating the slope of the first part of the extraction curve. The solubility $y_{s}$ with the SC- $\mathrm{CO}_{2}$ density $\rho \mathrm{CO}_{2}$, the mass transfer coefficient $k_{f}$ and the diffusion coefficient $D_{21}$ of the extracted oil are reported in Table 2. Fig. 6(a)-(c) shows the plot of $\ln \left(y_{s}\right)$ versus $\ln \left(\rho \mathrm{CO}_{2}\right)$ at 313,323 and $333 \mathrm{~K}$, the linearity is very good. In Fig. 6 (d) the experimental data of $y_{s}$ were correlated with the Chrastil equation. The correlation obtained in the study conditions is given in Eq. (16), the corresponding AARD is about $1.3 \%$.

$\ln \left(y_{s}\right)=5.294 \ln \rho_{\mathrm{CO}_{2}}+\frac{1323.26}{T}-45.595$

The experimental data were compared to the estimations made by Fernandez et al. [35] in Fig. 6(a)-(c). The solubility calculated in both studies is at the same order of magnitude. Moreover, the value of the oil solubility estimated in this present work is of the same order of magnitude as that calculated with the results of Micic et al. [31] and presented in part 4.2.4.

The highest value of the oil solubility was obtained at $40 \mathrm{MPa}$ and $313 \mathrm{~K}$, which was expected since the retrograde solubility zone goes up to $40 \mathrm{MPa}$. These operating conditions correspond otherwise to the most rapid extraction kinetics.

\subsubsection{Modelling}

The values of the model parameters fitted on the experimental data of JC are reported in Table 3. The AARD is comprised between 2.65 and $3.91 \%$ for the modelling performed on the experimental data reported in this study, suggesting that the extraction of type B from the BIC model is very well suited for describing the extraction curves from JC. Thanks to the modelling, it was possible to estimate the extraction time needed to complete the extraction by $\mathrm{SC}-\mathrm{CO}_{2}$. The estimates of the extraction times $t_{f}$ for total oil extraction by $\mathrm{SC}-\mathrm{CO}_{2}$ were also reported in Table 3.

At $40 \mathrm{MPa}$ and $313 \mathrm{~K}$ (Figs. Fig. 22(a) and Fig. 44(c)), the experimental data obtained exhibits only the solubility part, the last experiment point is very close to maximal yield. Due to the lack of experimental points, it was not possible to complete the modelling. Nevertheless, at these operating conditions the solute-matrix interactions are supposed to be very low and close to solubility. At $20 \mathrm{MPa}$ and $333 \mathrm{~K}$, the experimental extraction curve was not performed until its end, nevertheless the first and the second part of the extraction curve were visible. Hence, it was possible to make a predictive estimation to complete the extraction curve by using the BIC model. In this case, the model gives an order of magnitude of the parameters that should be obtained. A possible shape of the complete extraction curve at $20 \mathrm{MPa}$ and $333 \mathrm{~K}$ is given in Figs. Fig. 22(c) and Fig. 44(a).

The model parameters calculated show that, for a fixed pressure, the 

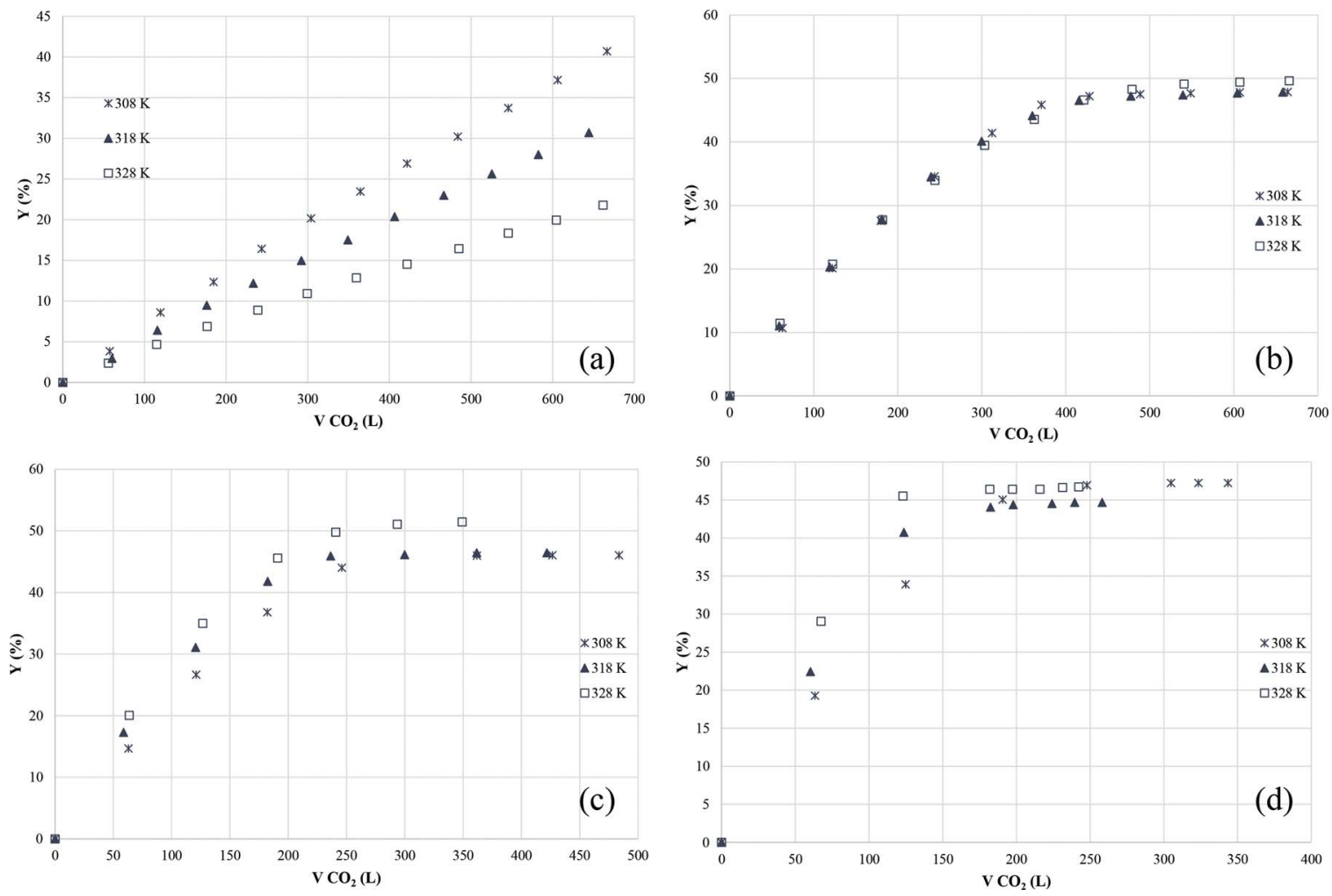

Fig. 5. Experimental SC- $\mathrm{CO}_{2}$ extraction curves plotted according to the data published by Min et al: Effects of temperature (a) $20 \mathrm{MPa}$, (b) $30 \mathrm{MPa}$, (c) $40 \mathrm{MPa}$, (d) $50 \mathrm{MPa}$.

Table 2

Transfer properties of JC oil in SC- $\mathrm{CO}_{2}$ : oil solubility, fluid phase mass transfer coefficient and diffusion coefficient.

\begin{tabular}{llllll}
\hline$P(\mathrm{MPa})$ & $T(\mathrm{~K})$ & $\begin{array}{l}\rho \mathrm{CO}_{2} \\
\left(\mathrm{~kg} / \mathrm{m}^{3}\right)\end{array}$ & $\begin{array}{l}y_{s} \times 10^{3}(\mathrm{~kg} \text { oil } / \\
\left.k g_{C O 2}\right)\end{array}$ & $\begin{array}{l}k_{f} \times 10^{5} \\
(\mathrm{~m} / \mathrm{s})\end{array}$ & $D_{21} \times 10^{9}\left(\mathrm{~m}^{2} / \mathrm{s}\right)$ \\
\hline \multirow{2}{*}{40} & 313 & 958 & 5.878 & 5.15 & 5.10 \\
& 323 & 925 & 4.735 & 5.68 & 5.55 \\
& 333 & 891 & 4.150 & 6.25 & 6.04 \\
30 & 313 & 907 & 4.585 & 5.82 & 5.62 \\
& 323 & 868 & 4.080 & 6.52 & 6.20 \\
& 333 & 827 & 1.783 & 7.32 & 6.90 \\
20 & 323 & 773 & 2.383 & 8.25 & 7.51 \\
& 333 & 717 & 1.024 & 9.76 & 8.70 \\
\hline
\end{tabular}

transition concentration $x_{t}$ is larger for smaller values of partition coefficient $K$. An increasing value of parameter $x_{t}$ associated to a decreasing value of parameter $K$ highlights an increase of the solute-matrix interactions. When the value of parameter $x_{t}$ increases, it can be observed that the transition between the first and second straight line of the extraction curve becomes sharper. The transitions became smooth with a decrease in the solute-matrix interactions (decreasing of $x_{t}$ ).

In the retrograde solubility zone, the solute-matrix interactions increased with an increasing temperature and with a decreasing pressure. When the value of parameter $K$ is low, the second straight line of the extraction curve is longer because of the low mass transfer. Hence, the time required to complete the extraction increases. The calculated values of grinding efficiency $r$ were found to be very close to 0.9 indicating that the pre-treatment applied in this study (grinding and sieving) was efficient. This result confirms the observations made by SEM. It was decided not to fix parameter $r$ at a single value as the grinded and sieved biomass introduced into the extraction autoclave is different in terms of shape of the powder from one sample to another involving differences in mass transfer.

When the solute-matrix interactions are weak, the transition between the second straight line and the diffusion part of the extraction curve is smooth. This transition became sharp when the solute-matrix interactions were high. Hence, when the solute matrix interactions are stronger, the diffusion process starts very late and appears to be fast. The end of the extraction curve (second and third part) is governed by solute-matrix interactions followed by fast diffusion. On the contrary, when solute-matrix interactions are low, the end of the extraction curve is mainly governed by diffusion. The transition can be evaluated by the value of the parameter $k_{s} a_{s}$, when the value of the parameter increases for a fixed value of pressure, the diffusion appears to be important at the end of the extraction curve.

To our knowledge, no modelling data using the BIC model have been reported about the extraction of oil from JC or about the use of the BIC model involving the extraction of type B. Consequently, it is not possible to make a comparison between the literature and the values of the parameters reported in this study. Hence, it has been decided to apply the type B, BIC model to the data published by Micic et al. [31]. The JC seeds used in this study came from Malaysia, the extraction was not performed until the end and the maximal extraction yield was not indicated. The pre-treatment applied was drying, milling and sieving to a mean particle diameter of $900 \mu \mathrm{m}$. Lim et al. [30] studied SC- $\mathrm{CO}_{2}$ extraction with co-solvents using JC seeds from Malaysia, they also performed Soxhlet extraction on the kernels. They found that the total oil content in JC kernels was about $64.59 \mathrm{wt} \%$. Considering this data, the value of $C_{u}$ was fixed at $0.6 \mathrm{~kg} / \mathrm{kg}$ for the modelling calculations. The bed void fraction $\varepsilon$ was fixed at 0.7 . The modelled extraction curve considering the data reported by Micic et al. [31]. is presented in Fig. 7, and the adjusted parameters are reported in Table 3.

The AARD was found to be $2.26 \%$ which is very satisfactory, and the calculated parameters are at the same order of magnitude than those obtained in this study. The parameter $r$ was found to be low: 0.28 showing that the pre-treatment was not efficient. The sieving should probably be lower than $900 \mu \mathrm{m}$ to increase the efficiency and then the value of parameter $r$. The parameter $k_{s} a_{s}$ was found to be very low, indicating that the diffusion at the end of the extraction process is very slow at can be seen in Fig. 7. Finally, at the same operating conditions 

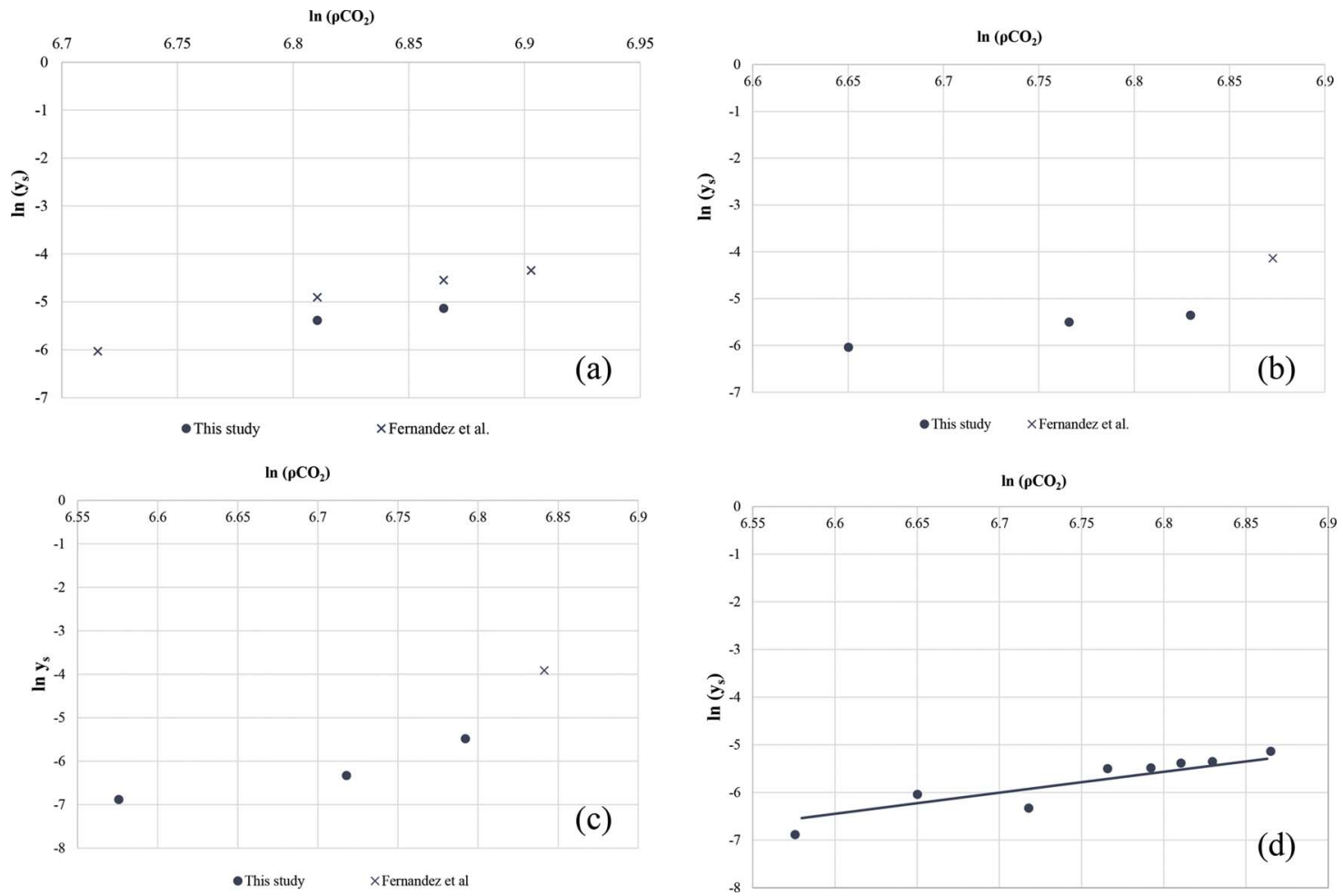

Fig. 6. JC oil solubility in $\mathrm{SC}-\mathrm{CO}_{2}$, plot of $\ln \left(y_{s}\right)$ versus $\ln \left(\rho_{\mathrm{CO} 2}\right)$ : (a) $313 \mathrm{~K}$, (b) $323 \mathrm{~K}$, (c) $333 \mathrm{~K}$, (d) Chrastil modelling at pressure from 20 up to $40 \mathrm{MPa}$ and temperature from 313 up to $333 \mathrm{~K}$.

Table 3

BIC model parameters (extraction of type B) evaluated from experimental data on JC.

\begin{tabular}{|c|c|c|c|c|c|c|c|c|c|c|c|}
\hline \multicolumn{12}{|c|}{ This study } \\
\hline$P(M P a)$ & $T(K)$ & $N \times 10^{3}(\mathrm{~kg})$ & $k_{s} a_{s} \times 10^{5}\left(\mathrm{~s}^{-1}\right)$ & $r$ & $K \times 10^{3}$ & $\begin{array}{l}x_{t}\left(\mathrm{~kg}_{\text {oil }} /\right. \\
\left.k g_{\text {insolublesolid }}\right)\end{array}$ & $\begin{array}{l}\Upsilon\left(k_{\mathrm{CO} 2} /\right. \\
\left.k g_{\text {insolublesolid }}\right)\end{array}$ & $\begin{array}{l}q_{1}\left(k_{\mathrm{CO} 2} /\right. \\
\left.k g_{\text {biomass }}\right)\end{array}$ & $\begin{array}{l}q_{c}\left(\mathrm{~kg}_{\mathrm{CO} 2} /\right. \\
\left.k g_{\text {biomass }}\right)\end{array}$ & AARD (\%) & $t_{f}(\mathrm{~h})$ \\
\hline \multirow[t]{3}{*}{40} & 313 & 8.776 & - & - & - & - & - & - & - & - & $2.2-3.3$ \\
\hline & 323 & 8.537 & 1.4471 & 0.94 & 2.55 & 1.28 & 3.36 & 134.11 & 364.98 & 2.65 & 4.3 \\
\hline & 333 & 7.465 & 0.1713 & 0.98 & 2.36 & 1.40 & 3.36 & 101.28 & 415.75 & 2.93 & 5.6 \\
\hline \multirow[t]{3}{*}{30} & 313 & 7.085 & 1.6719 & 0.92 & 2.25 & 1.16 & 3.29 & 154.40 & 394.36 & 3.35 & 5.3 \\
\hline & 323 & 7.055 & 0.3680 & 0.96 & 1.61 & 1.19 & 3.15 & 133.88 & 591.35 & 3.51 & 7.1 \\
\hline & 333 & 7.019 & 0.4168 & 0.98 & 0.92 & 1.37 & 3.00 & 229.47 & 1031.60 & 3.91 & 8.8 \\
\hline \multirow[t]{2}{*}{20} & 323 & 7.039 & 0.6551 & 0.80 & 0.70 & 1.20 & 2.81 & 62.04 & 387.68 & 3.52 & 24.6 \\
\hline & 333 & 7.087 & 0.0271 & 0.98 & 0.28 & 1.28 & 2.61 & 317.48 & 3516.87 & 3.00 & 35.4 \\
\hline \multicolumn{12}{|c|}{ Micic et al. } \\
\hline 30 & 323 & 50 & 0.0686 & 0.28 & 1.50 & 1.04 & 3.15 & 30.28 & 72.05 & 2.26 & 519 \\
\hline
\end{tabular}

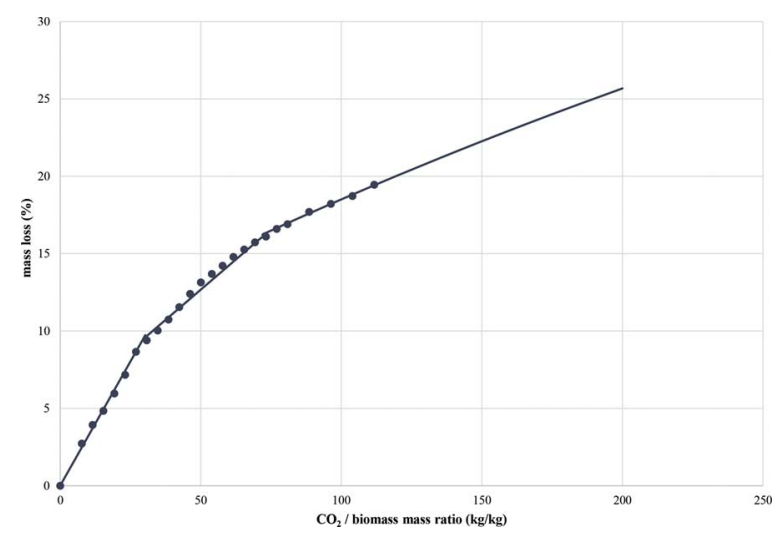

Fig. 7. JC SC- $-\mathrm{CO}_{2}$ extraction curve published by Micic et al. and modelled with BIC model (extraction of type $\mathrm{B}, \mathrm{P}=30 \mathrm{MPa}$ and $\mathrm{T}=323 \mathrm{~K}$ ). the solubility obtained from Micic et al. [31] data and from this work are at the same order of magnitude: 3.212 goil $/ \mathrm{kgCO}_{2}$ and 4.080 goil/ $\mathrm{kgCO}_{2}$, respectively.

It was not possible to apply the BIC model on the extraction curves published by Min et al. [30] and Fernandez et al. [35]. Indeed, in the study published by Min et al. [30], the values of the extraction yield were reported as a function of the volume of $\mathrm{CO}_{2}$ measured by a gas wet meter. The pressure and temperature of volume measurements were not reported making the conversion of the volume of $\mathrm{CO}_{2}$ into mass impossible. In the study of Fernandez et al. [35], the extraction curves were plotted according to the mass of oil collected at the end of the extraction line. On the extraction curves, it was not possible to clearly detect the three parts of the extraction curves.

\subsection{JC oil analysis}

Oil analysis was performed by gas chromatography coupled with mass spectrometry and a flame ionization detector (GC/MS-FID) equipped with an Agilent ZB-WAX column $(0.25 \mathrm{~mm} \times 30 \mathrm{~m})$, the 
Table 4

Fatty acids composition of fresh JC kernels.

\begin{tabular}{lll}
\hline Fatty acid & $\mu \mathrm{g} / \mathrm{mg}$ & mass fraction (\%) \\
\hline Palmitic C16:0 & 54.0 & 5.4 \\
Palmitoleic C16:1 & 2.8 & 0.3 \\
Stearic C18:0 & 20.6 & 2.1 \\
Oleic C18:1 & 112.3 & 11.2 \\
c18:1b & 4.0 & 0.4 \\
Linoleic C18:2 & 100.1 & 10.0 \\
Total & 293.8 & 29.4
\end{tabular}

Table 5

Comparison of the FAME profile of the JC oil (before and after extraction).

\begin{tabular}{|c|c|c|c|c|c|c|c|}
\hline \multicolumn{8}{|c|}{ Fatty acids (\%) } \\
\hline $\mathrm{P}(\mathrm{MPa})$ & $\mathrm{T}(\mathrm{K})$ & C16:0 & C16:1 & C18:0 & C18:1 & C18:1b & C18:2 \\
\hline \multirow[t]{3}{*}{40} & 333 & 21.30 & 0.90 & 7.87 & 37.58 & 1.35 & 31.00 \\
\hline & 323 & 19.46 & 1.18 & 6.85 & 38.33 & 1.42 & 32.76 \\
\hline & 313 & 20.63 & 1.20 & 6.48 & 38.72 & 1.37 & 31.60 \\
\hline \multirow[t]{3}{*}{30} & 333 & 19.29 & 1.07 & 7.21 & 39.52 & 1.35 & 31.58 \\
\hline & 323 & 20.46 & 1.02 & 7.41 & 38.11 & 1.32 & 31.70 \\
\hline & 313 & 19.87 & 1.09 & 7.21 & 37.99 & 1.30 & 32.54 \\
\hline \multirow[t]{2}{*}{20} & 323 & 18.69 & 1.09 & 6.73 & 38.76 & 1.35 & 33.38 \\
\hline & 313 & 17.88 & 1.15 & 7.23 & 39.87 & 1.54 & 32.31 \\
\hline \multicolumn{2}{|c|}{ n-hexane extraction } & 18.45 & 1.09 & 6.73 & 38.25 & 1.36 & 34.13 \\
\hline \multicolumn{2}{|c|}{ JC oil before extraction } & 18.37 & 0.97 & 7.01 & 38.23 & 1.37 & 34.05 \\
\hline
\end{tabular}

carrier gas used was hydrogen. Fatty methyl esters were analyzed after transmethylation. The reagents were sulfuric acid in methanol with a concentration of $5 \%$, the temperature of reaction was $358 \mathrm{~K}$ and the reaction time $1 \mathrm{~h} 30$. The JC kernel oil before extraction is rich in neutral lipids, indeed the content of polar lipids towards neutral lipids is about $2.3 \%(7 \mu \mathrm{g} / \mathrm{mg})$ and the percentage of free fatty acids towards triglycerides is about $25 \%$. Among polar lipids, can be quantified $28 \%$ of Phosphatidylcholine, $21 \%$ of Phosphatidylinositol and $23 \%$ of Phosphatidylethanolamine. The FAME profile of JC oil before extraction is given in Table 4. Compared to the composition reported in the literature [16], the values reported appeared to be low. These differences are probably due to the variety and the growing conditions of the biomass used in this study.

The composition of the SC- $\mathrm{CO}_{2}$ extracted oil is given in Table 5 . As expected, the composition varies with the pressure and the temperature. The highest amount of total fatty acids is about $599 \mu \mathrm{g} / \mu \mathrm{L}$ and was obtained at $30 \mathrm{MPa}$ and $323 \mathrm{~K}$. At the operating conditions leading to the best extraction kinetics, the amount of fatty acids is about $519 \mu \mathrm{g} /$ $\mu \mathrm{L}$. The lowest amount $(485 \mu \mathrm{g} / \mu \mathrm{L})$ was obtained at $40 \mathrm{MPa}$ and $323 \mathrm{~K}$. Whatever the operating conditions used for SC- $\mathrm{CO}_{2}$ extraction, no polar lipids were extracted. In the oil obtained at $40 \mathrm{MPa}, 313 \mathrm{~K}$, the amount of free fatty acids towards triglycerides is close to 0 .

The composition of the $n$-hexane extracted oil is also given in Table 5. The amount of total fatty acids is about $441 \mu \mathrm{g} / \mu \mathrm{L}$ which is lower than the amounts extracted by $\mathrm{SC}-\mathrm{CO}_{2}$. The percentage of free fatty acids towards triglycerides is about $6 \%$. Furthermore, polar lipids were also extracted $(1.8 \mathrm{mg} / \mathrm{mL})$. To complete the extraction of total fatty acids by $n$-hexane extraction, a higher extraction time is needed. Whatever the operating conditions used for $\mathrm{SC}-\mathrm{CO}_{2}$ extraction no polar lipids were extracted. In the oil obtained at $40 \mathrm{MPa}, 313 \mathrm{~K}$, the amount of free fatty acids towards triglycerides is close to 0 . It appears that the FAME profile is independent of the extraction method and remains the same than in the initial biomass.

\section{Conclusion}

In this work, an experimental campaign of supercritical extraction of oil from Jatropha curcas kernels has been performed. The modelling of the extraction kinetics was studied by applying the BIC model with extraction of type B. Extraction of type B implies that the first part of the extraction curve can be divided into two distinct linear parts: one controlled by the JC oil solubility in $\mathrm{SC}-\mathrm{CO}_{2}$ and the second linear part highlighting solute-matrix interactions. The following part of the extraction curve is controlled by solute diffusion from intact cells to broken cells.

It was found that this model was very well suited to the $\mathrm{SC}-\mathrm{CO}_{2}$ oil extraction from JC. Whatever the conditions of pressure and temperature applied in this study, the asymptotic yield at infinite time was found to be always the same. The solubility of JC oil in $\mathrm{SC}-\mathrm{CO}_{2}$ was determined by the slope of the first extraction curve and was successfully modelled by the Chrastil equation.

The grinding of the biomass was the only pre-treatment applied and was found to be sufficient to obtain rapid extraction kinetics. A retrograde solubility zone was found at $20 \mathrm{MPa}$ and up to $40 \mathrm{MPa}$. The best extraction conditions in terms of kinetics, were obtained at $40 \mathrm{MPa}$ and $313 \mathrm{~K}$. Nevertheless, the highest amount of total fatty acids in the extract $(599 \mu \mathrm{g} / \mu \mathrm{L})$ was obtained at $30 \mathrm{MPa}$ and $323 \mathrm{~K}$. The FAME profile was found to be independent of the extraction method.

\section{Acknowledgment}

This work was conducted with financial support from Biocarb company France.

\section{References}

[1] W.M. Achten, E. Mathijs, L. Verchot, V.P. Singh, R. Aerts, B. Muys, Jatropha biodiesel fueling sustainability? Biofuels Bioprod. Biorefining. 1 (2007) 283-291.

[2] V.C. Pandey, K. Singh, J.S. Singh, A. Kumar, B. Singh, R.P. Singh, Jatropha curcas: a potential biofuel plant for sustainable environmental development, Renew. Sustain. Energy Rev. 16 (2012) 2870-2883, http://dx.doi.org/10.1016/j.rser.2012.02.004.

[3] H.C. Ong, A.S. Silitonga, H.H. Masjuki, T.M.I. Mahlia, W.T. Chong, M.H. Boosroh, Production and comparative fuel properties of biodiesel from non-edible oils: jatropha curcas, Sterculia foetida and Ceiba pentandra, Energy Convers. Manag. 73 (2013) 245-255, http://dx.doi.org/10.1016/j.enconman.2013.04.011.

[4] J. van Eijck, H. Romijn, Prospects for jatropha biofuels in Tanzania: an analysis with strategic niche management, Energy Policy 36 (2008) 311-325, http://dx.doi.org/ 10.1016/j.enpol.2007.09.016.

[5] M. Mofijur, H.H. Masjuki, M.A. Kalam, M.A. Hazrat, A.M. Liaquat, M. Shahabuddin, M. Varman, Prospects of biodiesel from Jatropha in Malaysia, Renew. Sustain. Energy Rev. 16 (2012) 5007-5020, http://dx.doi.org/10.1016/j.rser.2012.05.010.

[6] C.-Y. Yang, Z. Fang, B. Li, Y. Long, Review and prospects of Jatropha biodiesel industry in China, Renew. Sustain. Energy Rev. 16 (2012) 2178-2190, http://dx. doi.org/10.1016/j.rser.2012.01.043.

[7] W.M.J. Achten, L. Verchot, Y.J. Franken, E. Mathijs, V.P. Singh, R. Aerts, B. Muys, Jatropha bio-diesel production and use, Biomass Bioenergy 32 (2008) 1063-1084, http://dx.doi.org/10.1016/j.biombioe.2008.03.003.

[8] A.E. Atabani, T.M.I. Mahlia, H.H. Masjuki, I.A. Badruddin, H.W. Yussof, W.T. Chong, K.T. Lee, A comparative evaluation of physical and chemical properties of biodiesel synthesized from edible and non-edible oils and study on the effect of biodiesel blending, Energy 58 (2013) 296-304, http://dx.doi.org/10.1016/j. energy 2013.05.040.

[9] M. Sánchez, F. Bergamin, E. Peña, M. Martínez, J. Aracil, A comparative study of the production of esters from Jatropha oil using different short-chain alcohols: optimization and characterization, Fuel 143 (2015) 183-188, http://dx.doi.org/10. 1016/j.fuel.2014.11.064.

[10] A.S. Silitonga, H.H. Masjuki, T.M.I. Mahlia, H.C. Ong, A.E. Atabani, W.T. Chong, A global comparative review of biodiesel production from jatropha curcas using different homogeneous acid and alkaline catalysts: study of physical and chemical properties, Renew. Sustain. Energy Rev. 24 (2013) 514-533, http://dx.doi.org/10. 1016/j.rser.2013.03.044.

[11] A.W. Go, S. Sutanto, S. Zullaikah, S. Ismadji, Y.-H. Ju, A new approach in maximizing and direct utilization of whole Jatropha curcas L. kernels in biodiesel production - Technological improvement, Renew. Energy 85 (2016) 759-765, http://dx.doi.org/10.1016/j.renene.2015.06.073.

[12] B.Y. Lim, R. Shamsudin, Baharudin B.T.H.T, R. Yunus, A review of processing and machinery for Jatropha curcas L. fruits and seeds in biodiesel production: harvesting, shelling, pretreatment and storage, Renew. Sustain. Energy Rev. 52 (2015) 991-1002, http://dx.doi.org/10.1016/j.rser.2015.07.077.

[13] E. Sánchez-Arreola, G. Martin-Torres, J.D. Lozada-Ramírez, L.R. Hernández, E.R. Bandala-González, H. Bach, Biodiesel production and de-oiled seed cake nutritional values of a Mexican edible Jatropha curcas, Renew. Energy 76 (2015) 143-147, http://dx.doi.org/10.1016/j.renene.2014.11.017.

[14] I.R. Huerga, M.S. Zanuttini, M.S. Gross, C.A. Querini, Biodiesel production from Jatropha curcas: integrated process optimization, Energy Convers. Manag. 80 
(2014) 1-9, http://dx.doi.org/10.1016/j.enconman.2013.12.058.

[15] M. Baldini, E. Bulfoni, C. Ferfuia, Seed processing and oil quality of Jatropha curcas L. on farm scale: a comparison with other energy crops, Energy Sustain. Dev. 19 (2014) 7-14, http://dx.doi.org/10.1016/j.esd.2013.12.005.

[16] N. Nazir, N. Ramli, D. Mangunwidjaja, E. Hambali, D. Setyaningsih, S. Yuliani, M.A. Yarmo, J. Salimon, Extraction, transesterification and process control in biodiesel production from Jatropha curcas, Eur. J. Lipid Sci. Technol. 111 (2009) 1185-1200, http://dx.doi.org/10.1002/ejlt.200800259.

[17] E. Subroto, R. Manurung, H.J. Heeres, A.A. Broekhuis, Mechanical extraction of oil from Jatropha curcas L. kernel: effect of processing parameters, Ind. Crops Prod. 63 (2015) 303-310, http://dx.doi.org/10.1016/j.indcrop.2014.06.018.

[18] E. Subroto, R. Manurung, H.J. Heeres, A.A. Broekhuis, Optimization of mechanical oil extraction from Jatropha curcas L. kernel using response surface method, Ind. Crops Prod. 63 (2015) 294-302, http://dx.doi.org/10.1016/j.indcrop.2014.08.050.

[19] A.N. Siregar, J.A. Ghani, C.H.C. Haron, M. Rizal, Z. Yaakob, S.K. Kamarudin, Comparison of oil press for jatropha oil: a review, Res. Agric. Eng. 61 (2016) 1-13, http://dx.doi.org/10.17221/22/2013-RAE.

[20] E. Sánchez-Arreola, G. Martin-Torres, J.D. Lozada-Ramírez, L.R. Hernández, E.R. Bandala-González, H. Bach, Biodiesel production and de-oiled seed cake nutritional values of a Mexican edible Jatropha curcas, Renew. Energy 76 (2015) 143-147, http://dx.doi.org/10.1016/j.renene.2014.11.017.

[21] Y. He, T. Peng, Y. Guo, S. Li, Y. Guo, L. Tang, F. Chen, Nontoxic oil preparation from Jatropha curcas L. seeds by an optimized methanol/n-hexane sequential extraction method, Ind. Crops Prod. 97 (2017) 308-315, http://dx.doi.org/10.1016/j.indcrop. 2016.12.034.

[22] J. Qian, H. Shi, Z. Yun, Preparation of biodiesel from Jatropha curcas L. oil produced by two-phase solvent extraction, Bioresour. Technol. 101 (2010) 7025-7031, http://dx.doi.org/10.1016/j.biortech.2010.04.018.

[23] J. Liu, P. Chen, J. He, L. Deng, L. Wang, J. Lei, L. Rong, Extraction of oil from Jatropha curcas seeds by subcritical fluid extraction, Ind. Crops Prod. 62 (2014) 235-241, http://dx.doi.org/10.1016/j.indcrop.2014.08.039.

[24] G. Kumar, Ultrasonic-assisted reactive-extraction is a fast and easy method for biodiesel production from Jatropha curcas oilseeds, Ultrason. Sonochem. 37 (2017) 634-639, http://dx.doi.org/10.1016/j.ultsonch.2017.02.018.

[25] A.W. Go, S. Sutanto, S. Zullaikah, S. Ismadji, Y.-H. Ju, A new approach in maximizing and direct utilization of whole Jatropha curcas L. kernels in biodiesel production - Technological improvement, Renew. Energy 85 (2016) 759-765, http://dx.doi.org/10.1016/j.renene.2015.06.073.

[26] G. Severa, M. Edwards, M.J. Cooney, Bio-oil extraction of Jatropha curcas with ionic liquid co-solvent: fate of biomass protein, Bioresour. Technol. 226 (2017) 255-261, http://dx.doi.org/10.1016/j.biortech.2016.11.125.

[27] M.M.S.M. Ghoreishi, Biodiesel Production from Natural Resources via Supercritical Fluid Extraction and Catalytic Transesterification Reaction, (2013) http://www. formatex.info/energymaterialsbook/book/230-238.pdf (Accessed 9 August 2017).

[28] C.-H. Chen, W.-H. Chen, C.-M.J. Chang, S.-M. Lai, C.-H. Tu, Biodiesel production from supercritical carbon dioxide extracted Jatropha oil using subcritical hydrolysis and supercritical methylation, J. Supercrit. Fluids 52 (2010) 228-234, http://dx. doi.org/10.1016/j.supflu.2009.12.010.

[29] C.-R. Chen, Y.-J. Cheng, Y.-C. Ching, D. Hsiang, C.-M.J. Chang, Green production of energetic Jatropha oil from de-shelled Jatropha curcas L. seeds using supercritical carbon dioxide extraction, J. Supercrit. Fluids 66 (2012) 137-143, http://dx.doi. org/10.1016/j.supflu.2012.01.010.

[30] S. Lim, K.-T. Lee, Influences of different co-solvents in simultaneous supercritical extraction and transesterification of Jatropha curcas L. seeds for the production of biodiesel, Chem. Eng. J. 221 (2013) 436-445, http://dx.doi.org/10.1016/j.cej. 2013.02.014.

[31] V. Mićić, S. Yusup, V. Damjanović, Y.H. Chan, Kinetic modelling of supercritical carbon dioxide extraction of sage (Salvia officinalis L.) leaves and jatropha (Jatropha curcas L.) seeds, J. Supercrit. Fluids 100 (2015) 142-145, http://dx.doi. org/10.1016/j.supflu.2015.01.018.

[32] E. Breet, Y. Nortjé, C. van Greuning, Supercritical carbon dioxide extracted oil from Jatropha curcas: directive for the biodiesel industry? J. Supercrit. Fluids 60 (2011) 38-44, http://dx.doi.org/10.1016/j.supflu.2011.07.023.

[33] W.-H. Chen, C.-H. Chen, C.-M.J. Chang, Y.-H. Chiu, D. Hsiang, Supercritical carbon dioxide extraction of triglycerides from Jatropha curcas L. seeds, J. Supercrit. Fluid 51 (2009) 174-180, http://dx.doi.org/10.1016/j.supflu.2009.08.010.

[34] J. Min, S. Li, J. Hao, N. Liu, Supercritical $\mathrm{CO}_{2}$ extraction of jatropha oil and solubility correlation, J. Chem. Eng. Data 55 (2010) 3755-3758, http://dx.doi.org/ 10.1021/je100289t.

[35] C.M. Fernández, L. Fiori, M.J. Ramos, Á. Pérez, J.F. Rodríguez, Supercritical extraction and fractionation of Jatropha curcas L. oil for biodiesel production, J. Supercrit. Fluids 97 (2015) 100-106, http://dx.doi.org/10.1016/j.supflu.2014.11. 010.

[36] Y. Tsuchiya, I. Okajima, T. Sako, Study on the performance and emissions of diesel engines fueled by jatropha crude oil extracted with supercritical $\mathrm{CO}_{2}, \mathrm{~J}$. Chem. Eng Jpn. 49 (2016) 217-223, http://dx.doi.org/10.1252/jcej.15we076.

[37] Y. Tsuchiya, T. Sako, I. Okajima, A. Yamamoto, Solubility characteristics and selective extraction of jatropha oil by super- and subcritical CO2 extraction, J. Chem. Eng. Jpn. 46 (2013) 250-254, http://dx.doi.org/10.1252/jcej.12we266.

[38] P.-Y. Chen, W.-H. Chen, S.-M. Lai, C.-M.J. Chang, Solubility of Jatropha and Aquilaria oils in supercritical carbon dioxide at elevated pressures, J. Supercrit. Fluids 55 (2011) 893-897, http://dx.doi.org/10.1016/j.supflu.2010.09.006.

[39] H. Sovová, Mathematical model for supercritical fluid extraction of natural products and extraction curve evaluation, J. Supercrit. Fluids 33 (2005) 35-52, http://dx doi.org/10.1016/j.supflu.2004.03.005.

[40] A. Mouahid, C. Crampon, S.-A.A. Toudji, E. Badens, Supercritical CO2 extraction of neutral lipids from microalgae: experiments and modelling, J Supercrit. Fluids 77 (2013) 7-16, http://dx.doi.org/10.1016/j.supflu.2013.01.024.

[41] A. Mouahid, C. Crampon, S.-A.A. Toudji, E. Badens, Effects of high water content and drying pre-treatment on supercritical $\mathrm{CO} 2$ extraction from Dunaliella salina microalgae: experiments and modelling, J. Supercrit. Fluids 116 (2016) 271-280, http://dx.doi.org/10.1016/j.supflu.2016.06.007.

[42] M. Solana, C.S. Rizza, A. Bertucco, Exploiting microalgae as a source of essential fatty acids by supercritical fluid extraction of lipids: comparison between Scenedesmus obliquus, Chlorella protothecoides and Nannochloropsis salina, J. Supercrit. Fluids 92 (2014) 311-318, http://dx.doi.org/10.1016/j.supflu.2014.06. 013.

[43] A. Mouahid, C. Dufour, E. Badens, Supercritical CO 2 extraction from endemic Corsican plants; comparison of oil composition and extraction yield with hydrodistillation method, J. CO2 Utiliz. 20 (2017) 263-273, http://dx.doi.org/10.1016/j. jcou.2017.06.003.

[44] C.-H. He, Prediction of binary diffusion coefficients of solutes in supercritical solvents, AIChE J. 43 (1997) 2944-2947.

[45] J. Shi, Y. Kakuda, X. Zhou, G. Mittal, Q. Pan, Correlation of mass transfer coefficien in the extraction of plant oil in a fixed bed for supercritical CO2, J. Food Eng. 78 (2007) 33-40, http://dx.doi.org/10.1016/j.jfoodeng.2005.08.050. 